\title{
Number of Self-Employed Women and Men - Analysis Based on the Sections of the Polish Economy
}

\begin{abstract}
Anna Turczak*
The relationship between gender of a person and their employment status has been examined in the article. The aim of the article is to answer the question of whether the fact that a given person is a woman or a man has an impact on their being either self-employed or an employee or helping in conducting family economic activity without agreed remuneration. The analysis has been carried out separately for seven selected sections of the Polish economy: 1. agriculture, forestry and fishing; 2. manufacturing; 3. construction; 4. trade and repair; 5. transportation and storage; 6. education; 7. human health and social work activities. Cramer's Vhas been used to examine the strength of relationships discussed in the article. A relevant test of significance has been used to verify the formulated statistical hypotheses.
\end{abstract}

Keywords: employment status, self-employed person, entrepreneurship, gender.

Submitted: 20.08.2016 | Accepted: 04.10.2016

\section{Liczba kobiet i mężczyzn pracujących na własny rachunek - analiza oparta na sekcjach polskiej gospodarki}

$W$ artykule zbadano zależność między ptcia osoby a tym, jaki jest jej status zatrudnienia. Celem artykułu jest odpowiedź na pytanie, czy fakt, iż dana osoba jest kobieta albo męzczyzna ma wplyw na to, że pracuje na wtasny rachunek, jest pracownikiem najemnym albo pomaga bez umownego wynagrodzenia w prowadzeniu rodzinnej dziatalności gospodarczej. Analiza przeprowadzona została oddzielnie dla siedmiu wybranych sekcji polskiej gospodarki: 1. rolnictwo, leśnictwo i rybactwo; 2. przetwórstwo przemystowe; 3. budownictwo; 4. handel $i$ naprawa; 5. transport i gospodarka magazynowa; 6. edukacja; 7. opieka zdrowotna i pomoc społeczna. Do zbadania sity rozpatrywanych $w$ artykule zależności użyto wspótczynnika V Cramera. Z kolei do zweryfikowania sformutowanych hipotez statystycznych wykorzystano odpowiedni test istotności.

Słowa kluczowe: status zatrudnienia, pracujący na własny rachunek, przedsiębiorczość, płeć.

Nadesłany: 20.08.2016 | Zaakceptowany do druku: 04.10.2016

JEL: C12, J71, L26

* Anna Turczak - PhD, The West Pomeranian Business School.

Mailing address: The West Pomeranian Business School (Zachodniopomorska Szkoła Biznesu w Szczecinie), ul. Żołnierska 53, 71-210 Szczecin; e-mail: aturczak@zpsb.pl. 


\section{Introduction}

There are many factors affecting the decision to commence own business activity. These factors include incentives and limitations in the macro- and microenvironment, as well as those related to a particular person and their personal attributes.

Willingness to run own company is sometimes effectively limited by a number of external barriers, many of which are of institutional nature. Specifically, the individual's inclination to start own business activity may be restrained by lack of proper entrepreneur-friendly conditions provided by the state. The main obstacles of this kind occurring in Poland include high taxes, burdensome administrative procedures, changeability of the provisions of law and the low quality of the said law (Brdulak and Jakubik, 2010, p. 84).

It is difficult to explicitly identify such a set of personal characteristics that predestines a particular individual for entrepreneurship. However, it has been confirmed by many surveys that increased independence is a very important reason for starting own business. Beyond doubt, the entrepreneurial traits are: need for achievement, decision-making skills, ability to operate in conditions of uncertainty, willingness to accept risk, ambition, need for self-realization, openness to change, flexibility and innovativeness. It does also appear that entrepreneurs have a stronger desire to be in control of their own fate (Brockhuas, 1980, p. 509). The decision to start operating own business may also result from the need to stand out from the crowd, improve social status or be respected by relatives and friends. Entrepreneurship is quite often a continuation of a family tradition (Bygrave and Zacharakis, 2011, p. 52).

Numerous studies conducted concerning the motivation of persons commencing own business activity enabled a differentiation between the pull and push factors (Bednarski and Sienkiewicz, 2009, p. 261). The first ones arise from the need and the latter - from necessity. The pull factors include, among others (Jagoda and Bąk-Grabowska, 2008, p. 137):

- need for self-determination and a sense of freedom,

- desire to create and develop the undertaking from the ground up,
- need to derive satisfaction from the professional development and doing what one likes,

- risk-taking propensity,

- desire to be an owner and exercise complete control,

- willingness to be the sole decision-maker in the issues regarding organization and time of work,

- drive for financial success, raising the standard of living for themselves and their families,

- desire to prove themselves and prove their value in their own eyes as well as in the eyes of the others.

In such cases the business is run at own initiative and because of the willingness to act, with motivation stemming from entrepreneurial traits (Misiak, 2013, p. 282). On the other hand, the push factors for undertaking own business activity are as follows (Gawrycka, Wasilczuk and Zwiech, 2007, pp. 111-112):

- unemployment and difficulties in finding a full-time position,

- dissatisfaction with current job and the resulting necessity to find a new one,

- insufficient level of current income and the resulting necessity to find another source of income.

In the aforementioned cases, the entrepreneurship is "forced" by hardships experienced by a particular person. In such a situation even a person lacking entrepreneurial skills who would never be interested in commencing own business activity in different circumstances may be induced to set up own business (Bury and Gil, 2013, p. 294). Unfortunately, Poland is one of the countries where the most common motivation to establish business activity is an economic necessity, not a personal choice (Zbierowski et al., 2012, p. 29).

The results of the comparison of the structures of male and female populations according to the employment status may prove particularly interesting. Such a comparison would give an answer to the question of how the fact of being a man or a woman affects being an employee, a selfemployed person or a contributing family worker. It is also interesting how big the scale of the existing difference between the percentage of self-employed men and women is and whether this difference increases or decreases year by year. Finding answers to the aforementioned questions 
has been the aim of the study conducted in the further part of this paper.

\section{Concept of the Conducted Study}

The sample included the employed inhabitants of Poland. For the purpose of this paper, they were divided into three disjoint and exhaustive categories, employment status being the criterion for this division. The following categories were defined:

1) employees, i.e. persons employed on the basis of employment contract;

2) self-employed persons, i.e. persons who conduct their own economic activity;

3) contributing family workers, i.e. persons who help in conducting family economic activity without agreed remuneration.

Two research tasks have been carried out for this paper:

1) The strength of the relationship between gender and employment status of a working inhabitant of Poland has been determined using Cramer's $V$;

2) Parametric test of significance was applied to determine whether the difference between the percentage of selfemployed women and the percentage of self-employed men is of statistical significance and the analysis was conducted separately for the following seven sections of the Polish economy:

- agriculture, forestry and fishing;

- manufacturing;

- construction;

- trade and repair;

- transportation and storage;

- education;

- human health and social work activities.

The following hypotheses were formulated regarding the specified research tasks:

1) Over the last ten years in Poland the nature of the relationship between gender and employment status has not changed, and the strength of the relationship between these characteristics has not diminished;

2) The percentage of self-employed women is still significantly lower than the percentage of self-employed men in the case of each of the seven analysed sections of the national economy and the difference between the sexes did not decrease in the period examined.

The analysis was conducted based on the data of the labour force survey which is published quarterly by the Polish Central Statistical Office (CSO). The survey is carried out in a continuous way. In each of the 13 weeks of the quarter, $1 / 13$ th part of the quarterly sample of dwellings is examined. The survey is constructed in such a way that every one of 13 weekly samples is not only the same size but has also the same structure. Such a method of observation presents the situation in the labour market during the entire quarter (Labour...: $4 Q 2015,2016$, p. 12).

\section{Analysis of the Gender Influence on the Distribution of the Employed Inhabitants of Poland According to Their Employment Status}

Information regarding the number of employed persons and their structure according to the employment status has been gathered for the period of 3Q2006-4Q2015. The data, obtained from the labour force survey conducted by the $\mathrm{CSO}$, allowed for defining the number of employed persons and their structure for men and women separately.

The set task is to examine the character and strength of the relationship between gender and employment status of the Polish inhabitants. The values of the $\chi^{2}$ (1) statistic and the $V^{(2)}$ statistic based on it have been calculated in order to carry out this task. The obtained results are presented in Table 1.

Based on data collected in Table 1 it can be stated that although between 2006 and 2015 the number of employed persons in Poland increased, the number of working women in the total number of the employed remained relatively stable at $44-45 \%$.

Between 2006 and 2015 there was a significant change in the structure of employed persons according to the employment status, namely the number of employees increased while the number of self-employed persons and contributing family workers decreased. Such a regularity can be observed in the population of both women and men.

Based on the data in Table 1 the conclusion can be made that in each of the examined quarters the number of employees and contributing family workers in the female population was higher than in the male population. In turn, the number of 
Table 1. Employed persons, their structure and analysis of the relationship between gender and employment status

\begin{tabular}{|c|c|c|c|c|c|c|c|c|}
\hline \multicolumn{2}{|c|}{ Time period } & \multirow[b]{2}{*}{$\stackrel{*}{5}$} & \multirow{2}{*}{$\begin{array}{l}\text { Total } \\
\text { number of } \\
\text { employed } \\
\text { (in thous.) }\end{array}$} & \multicolumn{3}{|c|}{ of which } & \multicolumn{2}{|c|}{$\begin{array}{l}\text { Goodness-of-fit } \\
\text { measures }\end{array}$} \\
\hline year & $\begin{array}{l}\text { quar- } \\
\text { ter* }\end{array}$ & & & $\begin{array}{c}\text { employees } \\
(\%)\end{array}$ & $\begin{array}{c}\text { self- } \\
\text { employed } \\
(\%)\end{array}$ & $\begin{array}{l}\text { contributing } \\
\text { family workers } \\
(\%)\end{array}$ & $\begin{array}{l}\text { chi-square } \\
\text { statistic } \\
\text { (in thous.) }\end{array}$ & $\begin{array}{c}\text { Cramer's } \\
V\end{array}$ \\
\hline \multirow{6}{*}{2006} & \multirow{3}{*}{$3 Q$} & $t$ & 14,926 & 75.53 & 19.46 & 5.01 & \multirow{3}{*}{183.4} & \multirow{3}{*}{0.111} \\
\hline & & $f$ & 6,659 & 78.01 & 15.30 & 6.68 & & \\
\hline & & $m$ & 8,267 & 73.53 & 22.80 & 3.67 & & \\
\hline & \multirow{3}{*}{$4 Q$} & $t$ & 14,911 & 76.31 & 19.52 & 4.16 & \multirow{3}{*}{185.3} & \multirow{3}{*}{0.111} \\
\hline & & $f$ & 6,624 & 78.91 & 15.37 & 5.72 & & \\
\hline & & $m$ & 8,287 & 74.24 & 22.84 & 2.92 & & \\
\hline \multirow{12}{*}{2007} & \multirow{3}{*}{$1 \mathrm{Q}$} & $t$ & 14,840 & 76.22 & 19.58 & 4.20 & \multirow{3}{*}{239.7} & \multirow{3}{*}{0.127} \\
\hline & & $f$ & 6,615 & 78.75 & 15.10 & 6.15 & & \\
\hline & & $m$ & 8,225 & 74.19 & 23.17 & 2.64 & & \\
\hline & \multirow{3}{*}{$2 Q$} & $t$ & 15,152 & 76.19 & 19.30 & 4.51 & \multirow{3}{*}{218.8} & \multirow{3}{*}{0.120} \\
\hline & & $f$ & 6,792 & 78.33 & 15.21 & 6.46 & & \\
\hline & & $m$ & 8,360 & 74.45 & 22.63 & 2.92 & & \\
\hline & \multirow{3}{*}{$3 Q$} & $t$ & 15,433 & 76.50 & 19.15 & 4.34 & \multirow{3}{*}{194.7} & \multirow{3}{*}{0.112} \\
\hline & & $f$ & 6,959 & 79.19 & 14.96 & 5.85 & & \\
\hline & & $m$ & 8,474 & 74.30 & 22.60 & 3.10 & & \\
\hline & \multirow{3}{*}{$4 Q$} & $t$ & 15,537 & 77.24 & 18.94 & 3.82 & \multirow{3}{*}{230.4} & \multirow{3}{*}{0.122} \\
\hline & & $f$ & 6,984 & 80.04 & 14.52 & 5.44 & & \\
\hline & & $m$ & 8,553 & 74.96 & 22.54 & 2.50 & & \\
\hline \multirow{12}{*}{2008} & & $t$ & 15,516 & 76.97 & 19.14 & 3.89 & & \\
\hline & $1 Q$ & $f$ & 6,949 & 79.29 & 14.99 & 5.71 & 229.0 & 0.121 \\
\hline & & $m$ & 8,567 & 75.08 & 22.50 & 2.42 & & \\
\hline & & $t$ & 15,690 & 76.53 & 19.32 & 4.14 & & \\
\hline & $2 Q$ & $f$ & 7,025 & 79.03 & 15.12 & 5.85 & 216.4 & 0.117 \\
\hline & & $m$ & 8,665 & 74.51 & 22.74 & 2.76 & & \\
\hline & & $t$ & 15,990 & 77.04 & 18.55 & 4.42 & & \\
\hline & $3 Q$ & $f$ & 7,164 & 79.59 & 14.29 & 6.11 & 222.5 & 0.118 \\
\hline & & $m$ & 8,826 & 74.96 & 22.00 & 3.04 & & \\
\hline & & $t$ & 16,006 & 77.76 & 18.21 & 4.03 & & \\
\hline & $4 Q$ & $f$ & 7,193 & 80.44 & 13.78 & 5.78 & 252.4 & 0.126 \\
\hline & & $m$ & 8,813 & 75.58 & 21.82 & 2.60 & & \\
\hline & & $t$ & 15,715 & 77.12 & 19.05 & 3.83 & & \\
\hline & $1 \mathrm{Q}$ & $f$ & 7,078 & 80.25 & 14.33 & 5.43 & 252.8 & 0.127 \\
\hline 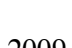 & & $m$ & 8,637 & 74.55 & 22.92 & 2.52 & & \\
\hline 2009 & & $t$ & 15,848 & 76.96 & 19.15 & 3.89 & & \\
\hline & $2 Q$ & $f$ & 7,134 & 79.52 & 14.80 & 5.68 & 246.1 & 0.125 \\
\hline & & $m$ & 8,714 & 74.87 & 22.71 & 2.42 & & \\
\hline
\end{tabular}


Table 1. cont.

\begin{tabular}{|c|c|c|c|c|c|c|c|c|}
\hline \multicolumn{2}{|c|}{ Time period } & \multirow[b]{2}{*}{$\stackrel{5}{5}$} & \multirow{2}{*}{$\begin{array}{c}\text { Total } \\
\text { number of } \\
\text { employed } \\
\text { (in thous.) }\end{array}$} & \multicolumn{3}{|c|}{ of which } & \multicolumn{2}{|c|}{$\begin{array}{l}\text { Goodness-of-fit } \\
\text { measures }\end{array}$} \\
\hline year & $\begin{array}{l}\text { quar- } \\
\text { ter* }\end{array}$ & & & $\begin{array}{c}\text { employees } \\
(\%)\end{array}$ & $\begin{array}{c}\text { self- } \\
\text { employed } \\
(\%)\end{array}$ & $\begin{array}{c}\text { contributing } \\
\text { family workers } \\
(\%)\end{array}$ & $\begin{array}{l}\text { chi-square } \\
\text { statistic } \\
\text { (in thous.) }\end{array}$ & $\begin{array}{c}\text { Cramer's } \\
V\end{array}$ \\
\hline \multirow{6}{*}{2009} & \multirow{3}{*}{$3 Q$} & $t$ & 16,026 & 77.14 & 18.60 & 4.26 & \multirow{3}{*}{255.9} & \multirow{3}{*}{0.126} \\
\hline & & $f$ & 7,190 & 79.33 & 14.39 & 6.27 & & \\
\hline & & $m$ & 8,836 & 75.35 & 22.02 & 2.63 & & \\
\hline & \multirow{3}{*}{$4 Q$} & $t$ & 15,884 & 77.83 & 18.30 & 3.88 & \multirow{3}{*}{258.5} & \multirow{3}{*}{0.128} \\
\hline & & $f$ & 7,184 & 80.58 & 13.81 & 5.61 & & \\
\hline & & $m$ & 8,700 & 75.55 & 22.00 & 2.45 & & \\
\hline \multirow{12}{*}{2010} & \multirow{3}{*}{$1 \mathrm{Q}$} & $t$ & 15,575 & 77.10 & 19.22 & 3.68 & \multirow{3}{*}{262.9} & \multirow{3}{*}{0.130} \\
\hline & & $f$ & 7,084 & 80.42 & 14.36 & 5.22 & & \\
\hline & & $m$ & 8,491 & 74.33 & 23.28 & 2.39 & & \\
\hline & \multirow{3}{*}{$2 \mathrm{Q}$} & $t$ & 15,994 & 77.27 & 18.78 & 3.95 & \multirow{3}{*}{262.6} & \multirow{3}{*}{0.128} \\
\hline & & $f$ & 7,241 & 80.33 & 14.07 & 5.59 & & \\
\hline & & $m$ & 8,753 & 74.73 & 22.68 & 2.59 & & \\
\hline & \multirow{3}{*}{$3 Q$} & $t$ & 16,199 & 77.20 & 18.74 & 4.06 & \multirow{3}{*}{234.8} & \multirow{3}{*}{0.120} \\
\hline & & $f$ & 7,301 & 79.63 & 14.56 & 5.81 & & \\
\hline & & $m$ & 8,898 & 75.21 & 22.17 & 2.62 & & \\
\hline & \multirow{3}{*}{$4 Q$} & $t$ & 16,076 & 77.37 & 18.89 & 3.74 & \multirow{3}{*}{248.0} & \multirow{3}{*}{0.124} \\
\hline & & $f$ & 7,232 & 80.09 & 14.48 & 5.43 & & \\
\hline & & $m$ & 8,844 & 75.15 & 22.49 & 2.36 & & \\
\hline \multirow{12}{*}{2011} & & $t$ & 15,874 & 77.30 & 19.18 & 3.52 & & \\
\hline & $1 Q$ & $f$ & 7,189 & 80.60 & 14.40 & 5.01 & 257.3 & 0.127 \\
\hline & & $m$ & 8,685 & 74.58 & 23.13 & 2.29 & & \\
\hline & & $t$ & 16,165 & 77.35 & 19.00 & 3.66 & & \\
\hline & $2 Q$ & $f$ & 7,254 & 80.60 & 14.36 & 5.03 & 234.9 & 0.121 \\
\hline & & $m$ & 8,911 & 74.69 & 22.77 & 2.54 & & \\
\hline & & $t$ & 16,283 & 77.29 & 18.73 & 3.99 & & \\
\hline & $3 Q$ & $f$ & 7,257 & 80.02 & 14.54 & 5.44 & 205.0 & 0.112 \\
\hline & & $m$ & 9,026 & 75.09 & 22.09 & 2.81 & & \\
\hline & & $t$ & 16,202 & 77.58 & 18.79 & 3.63 & & \\
\hline & $4 Q$ & $f$ & 7,256 & 80.44 & 14.36 & 5.20 & 240.2 & 0.122 \\
\hline & & $m$ & 8,946 & 75.25 & 22.39 & 2.36 & & \\
\hline & & $t$ & 15,982 & 77.67 & 18.96 & 3.37 & & \\
\hline & $1 \mathrm{Q}$ & $f$ & 7,216 & 81.08 & 14.23 & 4.68 & 242.6 & 0.123 \\
\hline 0010 & & $m$ & 8,766 & 74.87 & 22.85 & 2.28 & & \\
\hline 2012 & & $t$ & 15,722 & 77.55 & 18.76 & 3.69 & & \\
\hline & $3 Q$ & $f$ & 6,972 & 80.61 & 14.19 & 5.21 & 233.3 & 0.151 \\
\hline & & $m$ & 8,750 & 75.11 & 22.41 & 2.48 & & \\
\hline
\end{tabular}


Table 1. cont.

\begin{tabular}{|c|c|c|c|c|c|c|c|c|}
\hline \multicolumn{2}{|c|}{ Time period } & \multirow[b]{2}{*}{$\stackrel{5}{5}$} & \multirow{2}{*}{$\begin{array}{c}\text { Total } \\
\text { number of } \\
\text { employed } \\
\text { (in thous.) }\end{array}$} & \multicolumn{3}{|c|}{ of which } & \multicolumn{2}{|c|}{$\begin{array}{c}\text { Goodness-of-fit } \\
\text { measures }\end{array}$} \\
\hline year & $\begin{array}{c}\text { quar- } \\
\text { ter* }\end{array}$ & & & $\begin{array}{c}\text { employees } \\
(\%)\end{array}$ & $\begin{array}{c}\text { self- } \\
\text { employed } \\
(\%)\end{array}$ & $\begin{array}{c}\text { contributing } \\
\text { family workers } \\
(\%)\end{array}$ & $\begin{array}{l}\text { chi-square } \\
\text { statistic } \\
\text { (in thous.) }\end{array}$ & $\begin{array}{c}\text { Cramer's } \\
V\end{array}$ \\
\hline \multirow{3}{*}{2012} & \multirow{3}{*}{$4 Q$} & $t$ & 15,636 & 77.95 & 18.53 & 3.51 & \multirow{3}{*}{238.4} & \multirow{3}{*}{0.123} \\
\hline & & $f$ & 6,954 & 81.26 & 13.82 & 4.92 & & \\
\hline & & $m$ & 8,682 & 75.31 & 22.31 & 2.38 & & \\
\hline \multirow{12}{*}{2013} & \multirow{3}{*}{$1 \mathrm{Q}$} & $t$ & 15,291 & 77.97 & 18.78 & 3.24 & \multirow{3}{*}{262.5} & \multirow{3}{*}{0.131} \\
\hline & & $f$ & 6,800 & 81.50 & 13.79 & 4.71 & & \\
\hline & & $m$ & 8,491 & 75.15 & 22.78 & 2.07 & & \\
\hline & \multirow{3}{*}{$2 Q$} & $t$ & 15,530 & 78.02 & 18.62 & 3.35 & \multirow{3}{*}{242.4} & \multirow{3}{*}{0.125} \\
\hline & & $f$ & 6,890 & 81.42 & 13.83 & 4.75 & & \\
\hline & & $m$ & 8,640 & 75.31 & 22.44 & 2.25 & & \\
\hline & \multirow{3}{*}{$3 Q$} & $t$ & 15,739 & 78.19 & 18.41 & 3.41 & \multirow{3}{*}{239.9} & \multirow{3}{*}{0.123} \\
\hline & & $f$ & 6,990 & 81.47 & 13.72 & 4.81 & & \\
\hline & & $m$ & 8,749 & 75.56 & 22.15 & 2.29 & & \\
\hline & \multirow{3}{*}{$4 Q$} & $t$ & 15,715 & 78.49 & 18.32 & 3.19 & \multirow{3}{*}{253.7} & \multirow{3}{*}{0.127} \\
\hline & & $f$ & 7,028 & 81.84 & 13.56 & 4.60 & & \\
\hline & & $m$ & 8,687 & 75.77 & 22.17 & 2.06 & & \\
\hline \multirow{12}{*}{2014} & \multirow{3}{*}{$1 \mathrm{Q}$} & $t$ & 15,574 & 78.43 & 18.39 & 3.18 & \multirow{3}{*}{275.7} & \multirow{3}{*}{0.133} \\
\hline & & $f$ & 7,011 & 82.00 & 13.39 & 4.61 & & \\
\hline & & $m$ & 8,563 & 75.51 & 22.48 & 2.01 & & \\
\hline & \multirow{3}{*}{$2 \mathrm{Q}$} & $t$ & 15,794 & 78.76 & 18.11 & 3.13 & & \\
\hline & & $f$ & 7,041 & 82.66 & 12.87 & 4.47 & 290.0 & 0.136 \\
\hline & & $m$ & 8,753 & 75.62 & 22.32 & 2.06 & & \\
\hline & & $t$ & 16,062 & 78.65 & 18.27 & 3.08 & & \\
\hline & $3 Q$ & $f$ & 7,128 & 82.25 & 13.29 & 4.46 & 275.6 & 0.131 \\
\hline & & $m$ & 8,934 & 75.78 & 22.25 & 1.97 & & \\
\hline & & $t$ & 16,017 & 78.74 & 18.27 & 2.98 & & \\
\hline & $4 Q$ & $f$ & 7,155 & 82.17 & 13.50 & 4.33 & 259.3 & 0.127 \\
\hline & & $m$ & 8,862 & 75.98 & 22.13 & 1.90 & & \\
\hline & & $t$ & 15,837 & 78.87 & 18.12 & 3.01 & & \\
\hline & $1 \mathrm{Q}$ & $f$ & 7,122 & 82.36 & 13.34 & 4.30 & 254.4 & 0.127 \\
\hline 3015 & & $m$ & 8,715 & 76.01 & 22.03 & 1.96 & & \\
\hline 2015 & & $t$ & 15,986 & 78.73 & 18.28 & 2.99 & & \\
\hline & $2 \mathrm{Q}$ & $f$ & 7,195 & 82.47 & 13.26 & 4.27 & 274.9 & 0.131 \\
\hline & & $m$ & 8,791 & 75.67 & 22.39 & 1.95 & & \\
\hline
\end{tabular}




\begin{tabular}{|c|c|c|c|c|c|c|c|c|}
\hline \multicolumn{2}{|c|}{ Time period } & \multirow[b]{2}{*}{$\stackrel{5}{5}$} & \multirow{2}{*}{$\begin{array}{c}\text { Total } \\
\text { number of } \\
\text { employed } \\
\text { (in thous.) }\end{array}$} & \multicolumn{3}{|c|}{ of which } & \multicolumn{2}{|c|}{$\begin{array}{l}\text { Goodness-of-fit } \\
\text { measures }\end{array}$} \\
\hline year & $\begin{array}{c}\text { quar- } \\
\text { ter* }\end{array}$ & & & $\begin{array}{c}\text { employees } \\
(\%)\end{array}$ & $\begin{array}{c}\text { self- } \\
\text { employed } \\
(\%)\end{array}$ & $\begin{array}{c}\text { contributing } \\
\text { family workers } \\
(\%)\end{array}$ & $\begin{array}{l}\text { chi-square } \\
\text { statistic } \\
\text { (in thous.) }\end{array}$ & $\begin{array}{c}\text { Cramer's } \\
V\end{array}$ \\
\hline \multirow{6}{*}{2015} & \multirow{3}{*}{$3 Q$} & $t$ & 16,234 & 78.47 & 18.54 & 2.99 & \multirow{3}{*}{257.3} & \multirow{3}{*}{0.126} \\
\hline & & $f$ & 7,257 & 82.20 & 13.61 & 4.19 & & \\
\hline & & $m$ & 8,977 & 75.46 & 22.51 & 2.03 & & \\
\hline & \multirow{3}{*}{$4 Q$} & $t$ & 16,280 & 79.00 & 18.18 & 2.83 & \multirow{3}{*}{244.7} & \multirow{3}{*}{0.123} \\
\hline & & $f$ & 7,295 & 82.44 & 13.53 & 4.03 & & \\
\hline & & $m$ & 8,985 & 76.20 & 21.95 & 1.85 & & \\
\hline
\end{tabular}

Source: own computation based on (Labour force survey in Poland: 3Q2006, 2007, p. 92; 4Q2006, 2007, p. 96; 1Q2007, 2007, p. 94; 2Q2007, 2007, p. 126; 3Q2007, 2007, p. 126; 4Q2007, 2008, p. 126; 1Q2008, 2008, p. 123; 2Q2008, 2008, p. 123; 3Q2008, 2009, p. 125; 4Q2008, 2009, p. 149; 1Q2009, 2009, p. 146; 2Q2009, 2009, p. 146; 3Q2009, 2010, p. 146; 4Q2009, 2010, p. 146; 1Q2010, 2010, p. 148; 2Q2010, 2010, p. 148; 3Q2010, 2011, p. 148; 4Q2010, 2011, p. 148; 1Q2011, 2011, p. 148; 2Q2011, 2011, p. 148; 3Q2011, 2012, p. 146; 4Q2011, 2012, p. 148; 1Q2012, 2012, p. 150; 3Q2012, 2013, p. 204; 4Q2012, 2013, p. 204; 1Q2013, 2013, p. 100; 2Q2013, 2013, p. 92; 3Q2013, 2014, p. 92; 4Q2013, 2014, p. 92; 1Q2014, 2014, p. 92; 2Q2014, 2014, p. 84; 3Q2014, 2015, p. 84; 4Q2014, 2015, p. 84; 1Q2015, 2015, p. 88; 2Q2015, 2015, table 2.3 in the form of Excel file; 3Q2015, 2016, table 2.3 in the form of Excel file; 4Q2015, 2016, p. 88).

self-employed persons was higher in the male population. Hence, it is justified to conclude that the nature of the relationship between the gender of the person and their employment status remained unchanged over the studied years. An important question, however, is whether and how the strength of this relationship changed in the past decade. The values of $V$ statistic received for particular quarters allow us to conclude that - what is extremely surprising - the strength of this relationship has not diminished.

\section{Testing for Differences Between the Fractions of Men and Women}

Women are self-employed relatively less frequently than men, as already presented in the calculations results in Table 1. This raises yet another question - whether the difference between the percentage of selfemployed women and the percentage of self-employed men diminishes or increases. Another issue is how big these differences are in the case of individual sections of the Polish economy. The studies carried out in the latter part of this paper will be helpful in answering these questions.

Seven selected sections of the Polish economy have been analysed. Figure 1 presents the structure of employment divided into discussed sections for quarterly data covering 3Q2006-4Q2015.

Figure 1 shows that in the last decade the number of persons employed in agriculture, forestry and fishing has decreased (from $16 \%$ to $11 \%$ ), whereas the ratio of persons employed in manufacturing, construction, trade and repair, transportation and storage, education, human health and social work activities sections to the total number of persons employed in the national economy has remained approximately on the same level. The total share of persons employed in the discussed seven sections in the fourth quarter of 2015 was $72 \%$ (compared to $77 \%$ in the 3Q2006). For example, the following sections were qualified as "other": information and communication, financial and insurance activities, accommodation and catering, arts, entertainment and recreation. 


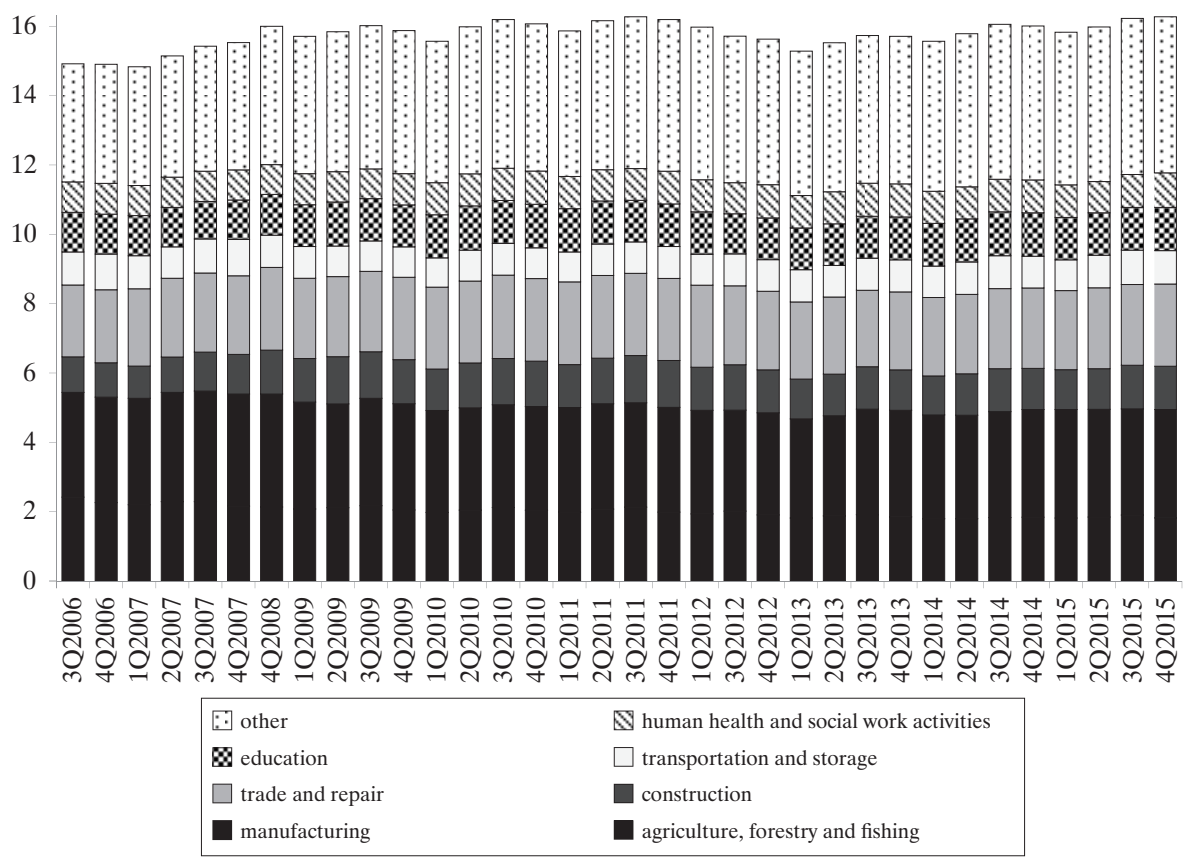

Source: as in Table 1.

The aim of the task is to answer the question of how big the differences are between the fraction of self-employed women and the fraction of self-employed men in the case of the analysed seven sections of the Polish economy, and establish whether those differences are on the increase or decrease. Properly selected parametric test of significance will contribute to perform this task.

In formal terms, the hypothesis of equality between the fraction of self-employed women $p_{K}$ and the fraction of such men $p_{M}$ shall be tested. Thus, it is necessary to verify the null hypothesis according to which $p_{K}=p_{M}$ against the alternative hypothesis stating that $p_{K}<p_{M}$. In order to carry out the verification procedure, it is essential to compute the value of statistic $z^{(3)}$. Table 2 contains information concerning the calculated statistic $z$ for the seven analysed sections of the Polish economy.

The next step is to determine the critical value $z_{\alpha}$, to which the values of the calculated statistic $z$ shall be compared. Let the level of significance be set at $\alpha=0.05$.For the left-hand side region of rejection the critical value $z_{\alpha}$ is -1.64 . The last columns of Table 2 contain information about the inequality sign between $z$ and $z_{\alpha}$ values. In the case of the sections:

- agriculture, forestry and fishing,

- manufacturing,

- trade and repair,

- transportation and storage,

- education,

- human health and social work activities there is a $z<z_{\alpha}$ inequality in the case of each quarter. Therefore the value of statistic $z$ was within the region of rejection and the null hypothesis had to be rejected in favour of the alternative hypothesis, at the same time stating that the fraction of self-employed women is significantly lower than the fraction of such men. In turn, in the construction section the value of statistic $z$ was within the area of rejection in the case of twenty quarters, whereas there is an inequality $z>z_{\alpha}$ in the case of fourteen quarters. It seems, however, that if the difference between the value of the test statistic $z$ and the critical value $z_{\alpha}$ increases from year to year, it is also justified to claim the significance of the difference between the fraction of self-employed men and women in the construction section. 
Table 2a. Calculations regarding significance of difference between the two fractions

\begin{tabular}{|c|c|c|c|c|c|c|c|c|c|}
\hline \multirow{2}{*}{\multicolumn{2}{|c|}{ Time period }} & \multicolumn{4}{|c|}{ Agriculture, forestry and fishing } & \multicolumn{4}{|c|}{ Manufacturing } \\
\hline & & \multirow{2}{*}{$\begin{array}{c}\text { total } \\
\text { number } \\
\text { of } \\
\text { employed } \\
\text { (in } \\
\text { thous.) }\end{array}$} & \multicolumn{2}{|c|}{\begin{tabular}{c|} 
share of self- \\
employed
\end{tabular}} & \multirow[b]{2}{*}{$\begin{array}{c}z \\
\text { sta- } \\
\text { tistic }\end{array}$} & \multirow{2}{*}{$\begin{array}{c}\text { total } \\
\text { number } \\
\text { of } \\
\text { employed } \\
\text { (in } \\
\text { thous.) }\end{array}$} & \multicolumn{2}{|c|}{$\begin{array}{c}\text { share of self- } \\
\text { employed }\end{array}$} & \multirow[b]{2}{*}{$\begin{array}{c}z \\
\text { sta- } \\
\text { tistic }\end{array}$} \\
\hline year & $\begin{array}{l}\text { quar- } \\
\text { ter* }\end{array}$ & & $\begin{array}{c}\text { in } \\
\text { the group } \\
\text { of } \\
\text { females }\end{array}$ & $\begin{array}{c}\text { in } \\
\text { the } \\
\text { group } \\
\text { of males }\end{array}$ & & & \begin{tabular}{|c|} 
in \\
the group \\
of \\
females
\end{tabular} & $\begin{array}{c}\text { in } \\
\text { the } \\
\text { group } \\
\text { of males }\end{array}$ & \\
\hline \multirow{2}{*}{2006} & $3 Q$ & 2,423 & 0.570 & 0.678 & -5.48 & 3,020 & 0.036 & 0.081 & -4.76 \\
\hline & $4 Q$ & 2,268 & 0.607 & 0.719 & -5.60 & 3,037 & 0.038 & 0.081 & -4.45 \\
\hline \multirow{4}{*}{2007} & $1 \mathrm{Q}$ & 2,204 & 0.572 & 0.732 & -7.88 & 3,071 & 0.045 & 0.075 & -3.15 \\
\hline & $2 Q$ & 2,293 & 0.558 & 0.703 & -7.17 & 3,154 & 0.039 & 0.068 & -3.31 \\
\hline & $3 Q$ & 2,296 & 0.580 & 0.690 & -5.47 & 3,186 & 0.035 & 0.071 & -4.06 \\
\hline & $4 Q$ & 2,162 & 0.584 & 0.724 & -6.81 & 3,234 & 0.032 & 0.072 & -4.54 \\
\hline 2008 & $4 Q$ & 2,136 & 0.545 & 0.713 & -8.05 & 3,259 & 0.030 & 0.059 & -3.59 \\
\hline \multirow{4}{*}{2009} & $1 Q$ & 2,080 & 0.571 & 0.727 & -7.44 & 3,084 & 0.036 & 0.067 & -3.58 \\
\hline & $2 Q$ & 2,121 & 0.571 & 0.725 & -7.43 & 2,991 & 0.039 & 0.075 & -3.87 \\
\hline & $3 Q$ & 2,178 & 0.529 & 0.708 & -8.62 & 3,097 & 0.036 & 0.068 & -3.58 \\
\hline & $4 Q$ & 2,051 & 0.533 & 0.710 & -8.26 & 3,065 & 0.036 & 0.062 & -3.04 \\
\hline \multirow{4}{*}{2010} & $1 Q$ & 1,983 & 0.564 & 0.720 & -7.20 & 2,939 & 0.035 & 0.069 & -3.75 \\
\hline & $2 Q$ & 2,050 & 0.538 & 0.703 & -7.68 & 2,947 & 0.038 & 0.072 & -3.68 \\
\hline & $3 Q$ & 2,122 & 0.537 & 0.689 & -7.16 & 2,966 & 0.037 & 0.073 & -3.89 \\
\hline & $4 Q$ & 2,044 & 0.546 & 0.706 & -7.49 & 2,993 & 0.036 & 0.071 & -3.86 \\
\hline \multirow{4}{*}{2011} & $1 \mathrm{Q}$ & 1,986 & 0.565 & 0.719 & -7.13 & 3,022 & 0.036 & 0.067 & -3.50 \\
\hline & $2 Q$ & 2,076 & 0.565 & 0.700 & -6.33 & 3,041 & 0.030 & 0.068 & -4.31 \\
\hline & $3 Q$ & 2,131 & 0.539 & 0.674 & -6.33 & 3,013 & 0.030 & 0.069 & -4.40 \\
\hline & $4 Q$ & 1,989 & 0.540 & 0.711 & -7.83 & 3,023 & 0.036 & 0.071 & -3.82 \\
\hline \multirow{3}{*}{2012} & $1 \mathrm{Q}$ & 1,940 & 0.576 & 0.724 & -6.78 & 2,988 & 0.035 & 0.071 & -3.92 \\
\hline & $3 Q$ & 2,019 & 0.544 & 0.694 & -6.89 & 2,911 & 0.039 & 0.067 & -2.98 \\
\hline & $4 Q$ & 1,908 & 0.536 & 0.708 & -7.65 & 2,947 & 0.040 & 0.070 & -3.19 \\
\hline \multirow{4}{*}{2013} & $1 \mathrm{Q}$ & 1,818 & 0.557 & 0.725 & -7.44 & 2,865 & 0.035 & 0.074 & -4.04 \\
\hline & $2 Q$ & 1,881 & 0.554 & 0.704 & -6.67 & 2,890 & 0.040 & 0.077 & -3.67 \\
\hline & $3 Q$ & 1,919 & 0.546 & 0.698 & -6.80 & 3,044 & 0.040 & 0.074 & -3.50 \\
\hline & $4 Q$ & 1,851 & 0.549 & 0.720 & -7.58 & 3,075 & 0.036 & 0.070 & -3.63 \\
\hline \multirow{4}{*}{2014} & $1 \mathrm{Q}$ & 1,800 & 0.533 & 0.724 & -8.31 & 2,993 & 0.040 & 0.071 & -3.31 \\
\hline & $2 Q$ & 1,803 & 0.538 & 0.708 & -7.35 & 2,984 & 0.041 & 0.077 & -3.69 \\
\hline & $3 Q$ & 1,832 & 0.550 & 0.711 & -7.11 & 3,059 & 0.037 & 0.076 & -4.05 \\
\hline & $4 \mathrm{Q}$ & 1,843 & 0.553 & 0.729 & -7.82 & 3,108 & 0.037 & 0.072 & -3.83 \\
\hline \multirow{4}{*}{2015} & $1 \mathrm{Q}$ & 1,822 & 0.548 & 0.731 & -8.05 & 3,127 & 0.040 & 0.069 & -3.23 \\
\hline & $2 Q$ & 1,847 & 0.557 & 0.721 & -7.23 & 3,107 & 0.040 & 0.076 & -3.79 \\
\hline & $3 Q$ & 1,903 & 0.570 & 0.720 & -6.77 & 3,069 & 0.036 & 0.074 & -4.03 \\
\hline & $4 Q$ & 1,826 & 0.582 & 0.742 & -7.21 & 3,125 & 0.037 & 0.069 & -3.50 \\
\hline
\end{tabular}




\begin{tabular}{|c|c|c|c|c|c|c|c|c|c|}
\hline \multirow{2}{*}{\multicolumn{2}{|c|}{ Time period }} & \multicolumn{4}{|c|}{ Construction } & \multicolumn{4}{|c|}{ Trade and repair } \\
\hline & & \multirow{2}{*}{\begin{tabular}{|c|} 
total \\
number \\
of \\
employed \\
(in \\
thous.)
\end{tabular}} & \multicolumn{2}{|c|}{$\begin{array}{c}\text { share of self- } \\
\text { employed }\end{array}$} & \multirow[b]{2}{*}{$\begin{array}{c}z \\
\text { sta- } \\
\text { tistic }\end{array}$} & \multirow{2}{*}{$\begin{array}{c}\text { total } \\
\text { number } \\
\text { of } \\
\text { employed } \\
\text { (in } \\
\text { thous.) }\end{array}$} & \multicolumn{2}{|c|}{$\begin{array}{c}\text { share of self- } \\
\text { employed }\end{array}$} & \multirow[b]{2}{*}{$\begin{array}{c}z \\
\text { sta- } \\
\text { tistic }\end{array}$} \\
\hline year & $\begin{array}{c}\text { quar- } \\
\text { ter* }\end{array}$ & & $\begin{array}{c}\text { in } \\
\text { the group } \\
\text { of } \\
\text { females }\end{array}$ & $\begin{array}{c}\text { in } \\
\text { the } \\
\text { group } \\
\text { of males }\end{array}$ & & & \begin{tabular}{|c|} 
in \\
the group \\
of \\
females
\end{tabular} & $\begin{array}{c}\text { in } \\
\text { the } \\
\text { group } \\
\text { of males }\end{array}$ & \\
\hline \multirow{2}{*}{2006} & $3 Q$ & 1,026 & 0.150 & 0.195 & -0.85 & 2,075 & 0.157 & 0.299 & -7.74 \\
\hline & $4 Q$ & 994 & 0.147 & 0.193 & -0.94 & 2,106 & 0.169 & 0.282 & -6.24 \\
\hline \multirow{4}{*}{2007} & $1 Q$ & 927 & 0.204 & 0.199 & 0.08 & 2,233 & 0.168 & 0.287 & -6.73 \\
\hline & $2 Q$ & 1,020 & 0.172 & 0.190 & -0.37 & 2,272 & 0.160 & 0.294 & -7.71 \\
\hline & $3 Q$ & 1,124 & 0.179 & 0.206 & -0.53 & 2,281 & 0.158 & 0.277 & -6.95 \\
\hline & $4 Q$ & 1,145 & 0.147 & 0.208 & -1.21 & 2,267 & 0.166 & 0.274 & -6.22 \\
\hline 2008 & $4 Q$ & 1,268 & 0.131 & 0.193 & -1.40 & 2,386 & 0.159 & 0.275 & -6.88 \\
\hline \multirow{4}{*}{2009} & $1 \mathrm{Q}$ & 1,260 & 0.129 & 0.216 & -1.90 & 2,314 & 0.162 & 0.283 & -7.03 \\
\hline & $2 Q$ & 1,360 & 0.169 & 0.219 & -0.94 & 2,311 & 0.153 & 0.260 & -6.39 \\
\hline & $3 Q$ & 1,340 & 0.136 & 0.208 & -1.41 & 2,323 & 0.154 & 0.262 & -6.40 \\
\hline & $4 Q$ & 1,271 & 0.124 & 0.214 & -2.03 & 2,378 & 0.155 & 0.271 & -6.92 \\
\hline \multirow{4}{*}{2010} & $1 \mathrm{Q}$ & 1,197 & 0.141 & 0.242 & -2.11 & 2,360 & 0.158 & 0.278 & -7.06 \\
\hline & $2 Q$ & 1,299 & 0.073 & 0.231 & -3.33 & 2,361 & 0.154 & 0.275 & -7.21 \\
\hline & $3 Q$ & 1,333 & 0.110 & 0.222 & -2.27 & 2,405 & 0.153 & 0.277 & -7.43 \\
\hline & $4 Q$ & 1,311 & 0.148 & 0.232 & -1.74 & 2,379 & 0.158 & 0.275 & -6.97 \\
\hline \multirow{4}{*}{2011} & $1 Q$ & 1,237 & 0.140 & 0.227 & -1.96 & 2,386 & 0.162 & 0.280 & -6.97 \\
\hline & $2 Q$ & 1,315 & 0.100 & 0.219 & -2.52 & 2,384 & 0.166 & 0.272 & -6.27 \\
\hline & $3 Q$ & 1,364 & 0.139 & 0.215 & -1.60 & 2,371 & 0.164 & 0.276 & -6.59 \\
\hline & $4 Q$ & 1,355 & 0.144 & 0.220 & -1.68 & 2,367 & 0.159 & 0.277 & -6.97 \\
\hline \multirow{3}{*}{2012} & $1 \mathrm{Q}$ & 1,245 & 0.096 & 0.222 & -2.70 & 2,363 & 0.159 & 0.285 & -7.41 \\
\hline & $3 Q$ & 1,313 & 0.177 & 0.222 & -0.93 & 2,276 & 0.153 & 0.278 & -7.28 \\
\hline & $4 Q$ & 1,242 & 0.184 & 0.234 & -1.00 & 2,264 & 0.149 & 0.272 & -7.21 \\
\hline \multirow{4}{*}{2013} & $1 \mathrm{Q}$ & 1,146 & 0.164 & 0.244 & -1.48 & 2,224 & 0.149 & 0.282 & -7.68 \\
\hline & $2 Q$ & 1,202 & 0.133 & 0.232 & -2.10 & 2,223 & 0.151 & 0.295 & -8.22 \\
\hline & $3 Q$ & 1,221 & 0.118 & 0.238 & -2.63 & 2,207 & 0.146 & 0.295 & -8.53 \\
\hline & $4 Q$ & 1,169 & 0.145 & 0.240 & -1.99 & 2,251 & 0.147 & 0.268 & -7.11 \\
\hline \multirow{4}{*}{2014} & $1 \mathrm{Q}$ & 1,125 & 0.138 & 0.239 & -2.15 & 2,262 & 0.142 & 0.273 & -7.69 \\
\hline & $2 Q$ & 1,195 & 0.106 & 0.237 & -2.78 & 2,289 & 0.135 & 0.292 & -9.24 \\
\hline & $3 Q$ & 1,237 & 0.116 & 0.234 & -2.65 & 2,312 & 0.143 & 0.291 & -8.74 \\
\hline & $4 Q$ & 1,188 & 0.112 & 0.227 & -2.53 & 2,320 & 0.149 & 0.265 & -6.90 \\
\hline \multirow{4}{*}{2015} & $1 Q$ & 1,152 & 0.115 & 0.227 & -2.30 & 2,280 & 0.136 & 0.259 & -7.46 \\
\hline & $2 Q$ & 1,172 & 0.110 & 0.227 & -2.47 & 2,335 & 0.128 & 0.264 & -8.37 \\
\hline & $3 Q$ & 1,257 & 0.110 & 0.217 & -2.42 & 2,329 & 0.132 & 0.263 & -7.95 \\
\hline & $4 Q$ & 1,246 & 0.155 & 0.222 & -1.44 & 2,376 & 0.127 & 0.251 & -7.81 \\
\hline
\end{tabular}


Table 2c. Calculations regarding significance of difference between the two fractions - continued

\begin{tabular}{|c|c|c|c|c|c|c|c|c|c|}
\hline \multirow{2}{*}{\multicolumn{2}{|c|}{ Time period }} & \multicolumn{4}{|c|}{ Transportation and storage } & \multicolumn{4}{|c|}{ Education } \\
\hline & & \multirow{2}{*}{$\begin{array}{c}\text { total } \\
\text { number } \\
\text { of } \\
\text { employed } \\
\text { (in } \\
\text { thous.) }\end{array}$} & \multicolumn{2}{|c|}{$\begin{array}{c}\text { share of self- } \\
\text { employed }\end{array}$} & \multirow[b]{2}{*}{$\begin{array}{c}z \\
\text { sta- } \\
\text { tistic }\end{array}$} & \multirow{2}{*}{$\begin{array}{c}\text { total } \\
\text { number } \\
\text { of } \\
\text { employed } \\
\text { (in } \\
\text { thous.) }\end{array}$} & \multicolumn{2}{|c|}{$\begin{array}{c}\text { share of self- } \\
\text { employed }\end{array}$} & \multirow[b]{2}{*}{$\begin{array}{c}z \\
\text { sta- } \\
\text { tistic }\end{array}$} \\
\hline year & $\begin{array}{c}\text { quar- } \\
\text { ter* }\end{array}$ & & $\begin{array}{c}\text { in } \\
\text { the group } \\
\text { of } \\
\text { females }\end{array}$ & $\begin{array}{c}\text { in } \\
\text { the } \\
\text { group } \\
\text { of males }\end{array}$ & & & $\begin{array}{c}\text { in } \\
\text { the group } \\
\text { of } \\
\text { females }\end{array}$ & $\begin{array}{c}\text { in } \\
\text { the } \\
\text { group } \\
\text { of males }\end{array}$ & \\
\hline \multirow{2}{*}{2006} & $3 Q$ & 951 & 0.072 & 0.157 & -3.15 & 1,145 & 0.006 & 0.039 & -4.15 \\
\hline & $4 Q$ & 1,029 & 0.049 & 0.162 & -4.35 & 1,153 & 0.009 & 0.035 & -3.03 \\
\hline \multirow{4}{*}{2007} & $1 \mathrm{Q}$ & 954 & 0.051 & 0.174 & -4.32 & 1,154 & 0.011 & 0.028 & -1.99 \\
\hline & $2 \mathrm{Q}$ & 903 & 0.082 & 0.151 & -2.46 & 1,138 & 0.006 & 0.036 & -3.87 \\
\hline & $3 Q$ & 985 & 0.094 & 0.155 & -2.28 & 1,083 & 0.008 & 0.049 & -4.29 \\
\hline & $4 Q$ & 1,051 & 0.073 & 0.168 & -3.73 & 1,137 & 0.013 & 0.045 & -3.13 \\
\hline 2008 & $4 Q$ & 930 & 0.082 & 0.179 & -3.44 & 1,179 & 0.014 & 0.058 & -4.11 \\
\hline \multirow{4}{*}{2009} & $1 \mathrm{Q}$ & 914 & 0.102 & 0.201 & -3.25 & 1,207 & 0.021 & 0.054 & -2.83 \\
\hline & $2 Q$ & 884 & 0.095 & 0.183 & -2.91 & 1,274 & 0.024 & 0.061 & -3.08 \\
\hline & $3 Q$ & 878 & 0.064 & 0.181 & -3.90 & 1,217 & 0.017 & 0.037 & -1.98 \\
\hline & $4 Q$ & 879 & 0.052 & 0.189 & -4.59 & 1,209 & 0.014 & 0.038 & -2.54 \\
\hline \multirow{4}{*}{2010} & $1 Q$ & 846 & 0.061 & 0.197 & -4.32 & 1,245 & 0.021 & 0.056 & -3.02 \\
\hline & $2 Q$ & 894 & 0.068 & 0.185 & -3.88 & 1,274 & 0.024 & 0.061 & -3.08 \\
\hline & $3 Q$ & 918 & 0.072 & 0.177 & -3.61 & 1,236 & 0.023 & 0.057 & -2.89 \\
\hline & $4 Q$ & 887 & 0.055 & 0.176 & -4.06 & 1,260 & 0.020 & 0.053 & -2.93 \\
\hline \multirow{4}{*}{2011} & $1 \mathrm{Q}$ & 867 & 0.052 & 0.194 & -4.48 & 1,244 & 0.018 & 0.057 & -3.45 \\
\hline & $2 Q$ & 906 & 0.077 & 0.192 & -3.70 & 1,243 & 0.020 & 0.079 & -4.85 \\
\hline & $3 Q$ & 909 & 0.089 & 0.171 & -2.71 & 1,197 & 0.015 & 0.078 & -5.37 \\
\hline & $4 Q$ & 920 & 0.063 & 0.176 & -3.75 & 1,230 & 0.020 & 0.059 & -3.46 \\
\hline \multirow{3}{*}{2012} & $1 Q$ & 894 & 0.067 & 0.180 & -3.69 & 1,223 & 0.018 & 0.057 & -3.56 \\
\hline & $3 Q$ & 919 & 0.058 & 0.176 & -4.03 & 1,157 & 0.020 & 0.071 & -4.11 \\
\hline & $4 Q$ & 912 & 0.059 & 0.171 & -3.80 & 1,207 & 0.021 & 0.057 & -3.16 \\
\hline \multirow{4}{*}{2013} & $1 Q$ & 931 & 0.063 & 0.170 & -3.67 & 1,207 & 0.020 & 0.062 & -3.70 \\
\hline & $2 \mathrm{Q}$ & 912 & 0.055 & 0.167 & -3.87 & 1,198 & 0.019 & 0.070 & -4.23 \\
\hline & $3 Q$ & 926 & 0.047 & 0.159 & -4.05 & 1,209 & 0.017 & 0.069 & -4.49 \\
\hline & $4 Q$ & 923 & 0.061 & 0.157 & -3.51 & 1,237 & 0.022 & 0.074 & -4.21 \\
\hline \multirow{4}{*}{2014} & $1 Q$ & 908 & 0.071 & 0.163 & -3.24 & 1,234 & 0.024 & 0.063 & -3.24 \\
\hline & $2 Q$ & 937 & 0.036 & 0.157 & -4.44 & 1,242 & 0.017 & 0.059 & -3.72 \\
\hline & $3 Q$ & 949 & 0.048 & 0.150 & -4.57 & 1,267 & 0.012 & 0.059 & -4.63 \\
\hline & $4 Q$ & 913 & 0.051 & 0.155 & -3.77 & 1,252 & 0.022 & 0.054 & -2.87 \\
\hline \multirow{4}{*}{2015} & $1 \mathrm{Q}$ & 886 & 0.065 & 0.156 & -3.22 & 1,225 & 0.029 & 0.069 & -2.99 \\
\hline & $2 Q$ & 940 & 0.048 & 0.175 & -4.33 & 1,223 & 0.022 & 0.055 & -2.85 \\
\hline & $3 Q$ & 992 & 0.046 & 0.173 & -4.45 & 1,231 & 0.015 & 0.058 & -3.92 \\
\hline & $4 Q$ & 960 & 0.056 & 0.156 & -3.66 & 1,251 & 0.024 & 0.068 & -3.48 \\
\hline
\end{tabular}




\begin{tabular}{|c|c|c|c|c|c|c|c|c|c|c|c|c|}
\hline \multirow{2}{*}{\multicolumn{2}{|c|}{ Time period }} & \multicolumn{4}{|c|}{$\begin{array}{l}\text { Human health and social work } \\
\text { activities }\end{array}$} & \multicolumn{7}{|c|}{ Inequality sign between $z$ and $z_{\alpha}$ values } \\
\hline & & \multirow[b]{2}{*}{ 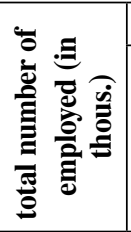 } & \multicolumn{2}{|c|}{ share of self-employed } & \multirow[b]{2}{*}{ 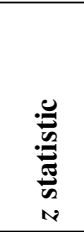 } & \multirow[b]{2}{*}{ 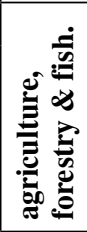 } & \multirow[b]{2}{*}{ 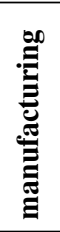 } & \multirow[b]{2}{*}{ 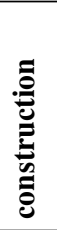 } & \multirow[b]{2}{*}{ 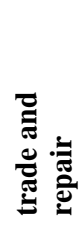 } & \multirow[b]{2}{*}{ 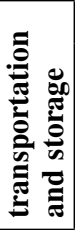 } & \multirow[b]{2}{*}{ } & \multirow[b]{2}{*}{ 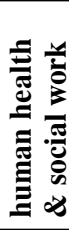 } \\
\hline year & 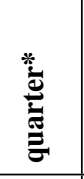 & & 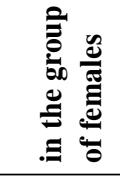 & 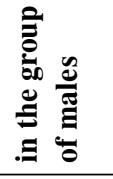 & & & & & & & & \\
\hline \multirow{2}{*}{2006} & $3 Q$ & 878 & 0.044 & 0.116 & -3.63 & $<$ & $<$ & $>$ & $<$ & $<$ & $<$ & $<$ \\
\hline & $4 Q$ & 886 & 0.052 & 0.148 & -4.42 & $<$ & $<$ & $>$ & $<$ & $<$ & $<$ & $<$ \\
\hline \multirow{4}{*}{2007} & $1 \mathrm{Q}$ & 871 & 0.061 & 0.147 & -3.82 & $<$ & $<$ & $>$ & $<$ & $<$ & $<$ & $<$ \\
\hline & $2 \mathrm{Q}$ & 874 & 0.061 & 0.149 & -3.82 & $<$ & $<$ & $>$ & $<$ & $<$ & $<$ & $<$ \\
\hline & $3 Q$ & 873 & 0.049 & 0.152 & -4.67 & $<$ & $<$ & $>$ & $<$ & $<$ & $<$ & $<$ \\
\hline & $4 Q$ & 866 & 0.048 & 0.122 & -3.49 & $<$ & $<$ & $>$ & $<$ & $<$ & $<$ & $<$ \\
\hline 2008 & $4 Q$ & 860 & 0.048 & 0.119 & -3.17 & $<$ & $<$ & $>$ & $<$ & $<$ & $<$ & $<$ \\
\hline \multirow{4}{*}{2009} & $1 \mathrm{Q}$ & 895 & 0.047 & 0.112 & -3.11 & $<$ & $<$ & $<$ & $<$ & $<$ & $<$ & $<$ \\
\hline & $2 Q$ & 872 & 0.051 & 0.120 & -3.26 & $<$ & $<$ & $>$ & $<$ & $<$ & $<$ & $<$ \\
\hline & $3 Q$ & 858 & 0.062 & 0.132 & -3.06 & $<$ & $<$ & $>$ & $<$ & $<$ & $<$ & $<$ \\
\hline & $4 Q$ & 900 & 0.062 & 0.160 & -4.14 & $<$ & $<$ & $<$ & $<$ & $<$ & $<$ & $<$ \\
\hline \multirow{4}{*}{2010} & $1 \mathrm{Q}$ & 926 & 0.060 & 0.140 & -3.53 & $<$ & $<$ & $<$ & $<$ & $<$ & $<$ & $<$ \\
\hline & $2 Q$ & 925 & 0.063 & 0.136 & -3.30 & $<$ & $<$ & $<$ & $<$ & $<$ & $<$ & $<$ \\
\hline & $3 Q$ & 932 & 0.071 & 0.167 & -3.98 & $<$ & $<$ & $<$ & $<$ & $<$ & $<$ & $<$ \\
\hline & $4 Q$ & 957 & 0.070 & 0.179 & -4.53 & $<$ & $<$ & $<$ & $<$ & $<$ & $<$ & $<$ \\
\hline \multirow{4}{*}{2011} & $1 Q$ & 932 & 0.067 & 0.126 & -2.59 & $<$ & $<$ & $<$ & $<$ & $<$ & $<$ & $<$ \\
\hline & $2 Q$ & 905 & 0.057 & 0.139 & -3.68 & $<$ & $<$ & $<$ & $<$ & $<$ & $<$ & $<$ \\
\hline & $3 Q$ & 917 & 0.069 & 0.173 & -4.26 & $<$ & $<$ & $>$ & $<$ & $<$ & $<$ & $<$ \\
\hline & $4 Q$ & 943 & 0.069 & 0.172 & -4.35 & $<$ & $<$ & $<$ & $<$ & $<$ & $<$ & $<$ \\
\hline \multirow{3}{*}{2012} & $1 \mathrm{Q}$ & 925 & 0.067 & 0.163 & -4.01 & $<$ & $<$ & $<$ & $<$ & $<$ & $<$ & $<$ \\
\hline & $3 Q$ & 897 & 0.069 & 0.165 & -4.03 & $<$ & $<$ & $>$ & $<$ & $<$ & $<$ & $<$ \\
\hline & $4 Q$ & 956 & 0.070 & 0.155 & -3.68 & $<$ & $<$ & $>$ & $<$ & $<$ & $<$ & $<$ \\
\hline \multirow{4}{*}{2013} & $1 \mathrm{Q}$ & 934 & 0.075 & 0.183 & -4.39 & $<$ & $<$ & $>$ & $<$ & $<$ & $<$ & $<$ \\
\hline & $2 Q$ & 926 & 0.077 & 0.191 & -4.52 & $<$ & $<$ & $<$ & $<$ & $<$ & $<$ & $<$ \\
\hline & $3 Q$ & 952 & 0.072 & 0.166 & -4.01 & $<$ & $<$ & $<$ & $<$ & $<$ & $<$ & $<$ \\
\hline & $4 Q$ & 955 & 0.069 & 0.149 & -3.46 & $<$ & $<$ & $<$ & $<$ & $<$ & $<$ & $<$ \\
\hline \multirow{4}{*}{2014} & $1 \mathrm{Q}$ & 926 & 0.070 & 0.159 & -3.72 & $<$ & $<$ & $<$ & $<$ & $<$ & $<$ & $<$ \\
\hline & $2 Q$ & 924 & 0.065 & 0.175 & -4.66 & $<$ & $<$ & $<$ & $<$ & $<$ & $<$ & $<$ \\
\hline & $3 Q$ & 939 & 0.081 & 0.170 & -3.66 & $<$ & $<$ & $<$ & $<$ & $<$ & $<$ & $<$ \\
\hline & $4 Q$ & 952 & 0.073 & 0.164 & -3.87 & $<$ & $<$ & $<$ & $<$ & $<$ & $<$ & $<$ \\
\hline \multirow{4}{*}{2015} & $1 \mathrm{Q}$ & 941 & 0.073 & 0.169 & -4.00 & $<$ & $<$ & $<$ & $<$ & $<$ & $<$ & $<$ \\
\hline & $2 Q$ & 902 & 0.074 & 0.189 & -4.40 & $<$ & $<$ & $<$ & $<$ & $<$ & $<$ & $<$ \\
\hline & $3 Q$ & 948 & 0.080 & 0.228 & -5.69 & $<$ & $<$ & $<$ & $<$ & $<$ & $<$ & $<$ \\
\hline & $4 Q$ & 996 & 0.086 & 0.194 & -4.36 & $<$ & $<$ & $>$ & $<$ & $<$ & $<$ & $<$ \\
\hline
\end{tabular}

* no data regarding the 1Q2008, 2Q2008, 3Q2008, and 2Q2012

Source: as in Table 1. 


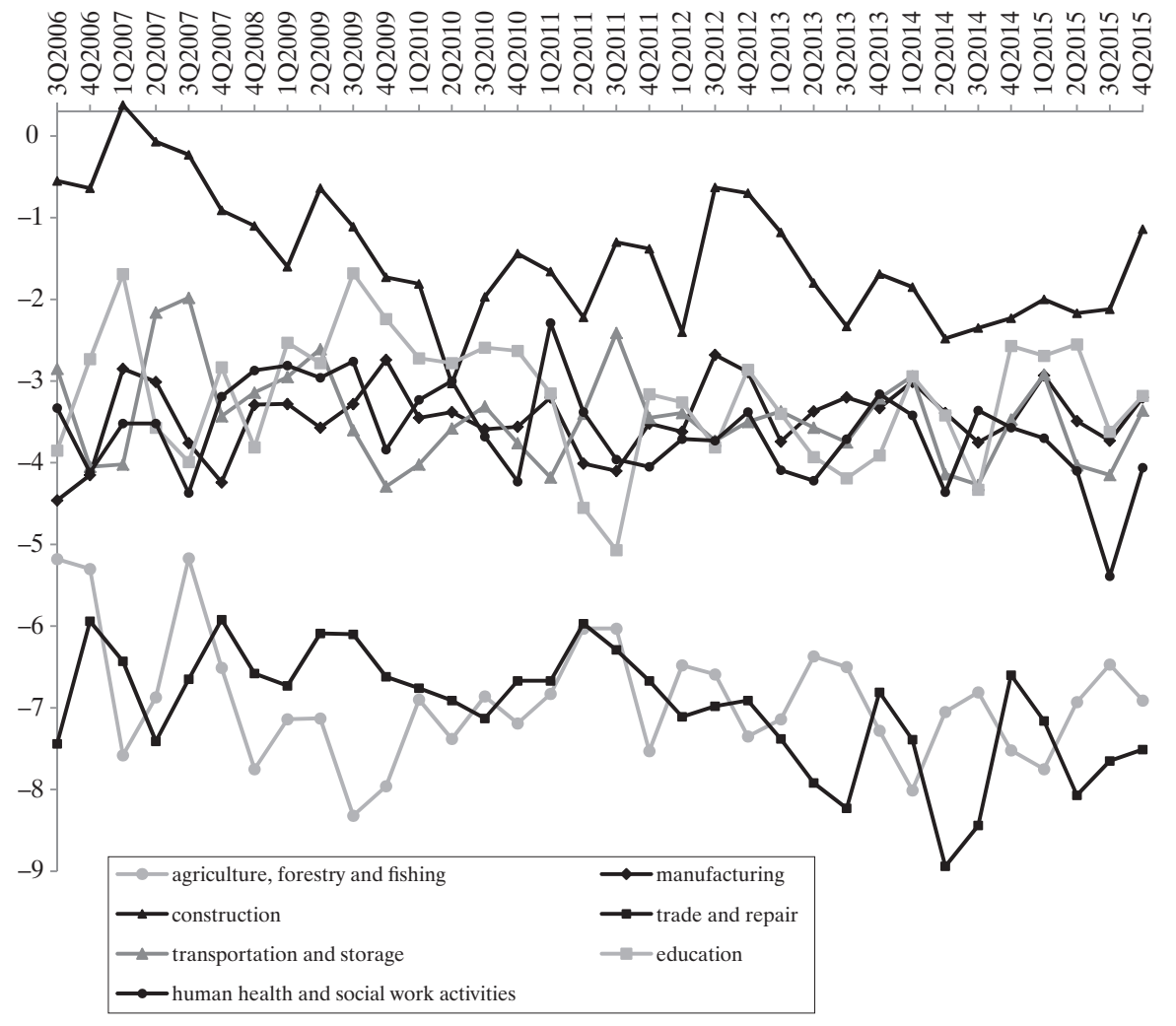

Source: own compilation based on Tables 1 and 2 .

Figure 2 shows the values of statistic $z$ obtained for the individual sections across all the examined quarters.

Based on Figure 2, it may be concluded that the highest disproportion in the numbers of self-employed women and men is observed in the following sections:

- agriculture, forestry and fishing,

- trade and repair.

There is a lower disproportion in the case of:

- manufacturing,

- transportation and storage,

- education,

- human health and social work activities.

The construction section is characterised by the lowest disproportion.

\section{Conclusions}

The comparison of the distribution of male and female populations according to the employment status has been made in this paper. Two research tasks have been carried out. The first research task verified how the fact that an adult inhabitant of Poland is a man or a woman affects being an employee, a self-employed person or a contributing family worker. The conducted study has shown that running own businesses is typical for men, while employees and contributing family members are more frequently women.

A number of detailed conclusions was made on completion of the second task. It has been shown that in the case of each of the seven analysed sections of the Polish economy gender significantly influences the decision whether to commence own business or not. What is particularly important, the differences between the sexes occurring in this regard from 3Q2006 to 4Q2015 have not decreased for any of the relevant sections. 


\section{Footnotes}

1 The value of the $\chi^{2}$ test statistic is calculated based on the formula (Ankarali and Cangur, 2013, p. 95):

$$
\chi^{2}=\sum_{i=1}^{r} \sum_{j=1}^{s} \frac{\left(n_{i j}-n_{i j}^{*}\right)^{2}}{n_{i j}^{*}},
$$

where $n_{i j}$ are empirical counts calculated for each $i$-th variant of the first characteristic and the $j$-th variant of the other characteristic, whereas $n^{*}{ }_{i j}$ are the theoretical counts corresponding to the various empirical counts $n_{i j}$.

2 Cramer's V is the unitless and normalized quantity - takes only the values of the range $<0,1>$ (Pułaska-Turyna, 2005, p. 254). If it is equal to 0 , there is no relationship between the statistical characteristics. In turn, the closer it is to 1 , the stronger the relationship is. Cramer's V is calculated according to the formula (Buga and Kassyk-Rokicka, 2008, p. 121):

$$
V=\sqrt{\frac{\chi^{2}}{n \cdot \min [(r-1),(s-1)]},}
$$

where $r$ is the number of variants of the first characteristic and $s$ is the number of variants of the second characteristic.

3 The value of the $z$ statistic is calculated based on the formula (Zeliaś, 2000, p. 275):

$$
z=\frac{p_{K}^{*}-p_{M}^{*}}{\sqrt{\bar{p}(1-\bar{p}) \frac{n_{K}+n_{M}}{n_{K} n_{M}}}},
$$

where:

$p^{*}{ }_{K}-$ the fraction of the selected persons in the sample of women,

$p^{*}{ }_{M}$ - the fraction of the selected persons in the sample of men,

$\mathrm{p}^{-}-$the mean fraction calculated from the joined samples of women and men.

\section{References}

Ankarali, H. and Cangur, S. (2013). Comparison of Pearson chi-square and log-likelihood ratio statistics in $\mathrm{R}^{\prime} \mathrm{C}$ tables with regard to type I error. International Journal of Basic and Clinical Studies, 2(2), 94-104.

Bednarski, M. and Sienkiewicz, L. (2009). Samozatrudnienie w wymiarze regionalnym. In: R.Cz. Horodeński and C. Sadowska-Snarska (eds.), Gospodarowanie zasobami pracy na poczatku XXI wieku. Aspekty makroekonomiczne i regionalne (pp. 257-272). Warsaw-Białystok: Instytut Pracy i Spraw Socjalnych and Wyższa Szkoła Ekonomiczna w Białymstoku.

Brdulak, J. and Jakubik, P. (2010). Instytucjonalne i kulturowe uwarunkowania przedsiębiorczości. In: K. Kuciński (ed.), Przedsiębiorczość a rozwój regionalny $w$ Polsce (pp. 80-89). Warsaw: Centrum Doradztwa i Informacji Difin.

Brockhuas, R. (1980). Risk-taking propensity of entrepreneurs. Academy of Management Journal, 23(3), 509-520.

Buga, J. and Kassyk-Rokicka, H. (2008). Podstawy statystyki opisowej. Warsaw: Wyższa Szkoła Finansów i Zarządzania w Warszawie.

Bury, P. and Gil, P. (2013). Samozatrudnienie - tendencje, szanse, bariery (z uwzględnieniem doświadczeń w AIP). In: S. Flejterski (ed.), Co z ta praca? Pomorze Zachodnie $w$ perspektywie interdyscyplinarnej i międzynarodowej (pp. 292-307). Szczecin: Wydawnictwo ZAPOL.

Bygrave, W. and Zacharakis, A. (2011). Entrepreneurship. John Wiley \& Sons, Inc.

Gawrycka, M., Wasilczuk, J. and Zwiech, P. (2007). Szklany sufit $i$ ruchome schody - kobiety na rynku pracy. Warsaw: Wydawnictwo CeDeWu.

Jagoda, A. and Bąk-Grabowska, D. (2008). Przedsiębiorczość a samozatrudnienie - dylematy terminologiczne. In: K. Jeremczuk (ed.), Uwarunkowania przedsiębiorczości - różnorodność $i$ zmienność (pp. 136-140). Tarnobrzeg: Państwowa Wyższa Szkoła Zawodowa w Tarnobrzegu.

Labour force survey in Poland: 3Q2006 (4Q2006, 1Q2007, 2Q2007, 3Q2007, 4Q2007, 1Q2008, 2Q2008, 3Q2008, 4Q2008, 1Q2009, 2Q2009, $3 Q 2009,4 Q 2009,1 Q 2010,2 Q 2010,3 Q 2010$, 4Q2010, 1Q2011, 2Q2011, 3Q2011, 4Q2011, $1 Q 2012,3 Q 2012,4 Q 2012,1 Q 2013,2 Q 2013$, 3Q2013, 4Q2013, 1Q2014, 2Q2014, 3Q2014, 4Q2014, 1Q2015, 2Q2015, 3Q2015, 4Q2015), 2007 (2008, 2009, 2010, 2011, 2012, 2013, 2014, 2015, 2016). Warsaw: Central Statistical Office.

Misiak, S. (2013). Praca na własny rachunek - wady i zalety według przedsiębiorczych kobiet. In: S. Flejterski (ed.), Co z ta pracq? Pomorze Zachodnie $w$ perspektywie interdyscyplinarnej i międzynarodowej (pp. 280-291). Szczecin: Wydawnictwo ZAPOL.

Pułaska-Turyna, B. (2005). Statystyka dla ekonomistów. Warsaw: Centrum Doradztwa i Informacji Difin.

Zbierowski, P., Węcławska, D., Tarnawa, A., Zadura-Lichota, P. and Bratnicki, M. (2012). Global Entrepreneurship Monitor. Polska. Warsaw: Polska Agencja Rozwoju Przedsiębiorczości.

Zeliaś, A. (2000). Metody statystyczne. Warsaw: Polskie Wydawnictwo Ekonomiczne. 